\title{
Bioactive compounds of Cheonggukjang prepared by different soybean cultivars with Bacillus subtilis HJ18-9
}

\author{
Jin Song*, Kyung-Ha Lee, Hye-Sun Choi, Kyung-A Hwang \\ National Academy of Agricultural Science, RDA, Wanju 55365, Korea
}

\section{Bacillus subtilis HJ18-9 이용하여 제조한 품종별 청국장의 품질특성과 isoflavone 함량의 변화}

\author{
송진* · 이경하·최혜선 · 황경아 \\ 농촌진흥청 국립농업과학원
}

\begin{abstract}
This study was conducted to investigate the changes of isoflavone composition (glycoside and bio-active aglycone) in Cheonggukjang and to evaluate its quality characteristics depending on different soybean cultivars (Daewon, Daepoong, Wooram, Hwangkeumol and Saedanback). The bioactivity of Cheonggukjang was enhanced during fermentation at $37^{\circ} \mathrm{C}$ for $48 \mathrm{~h}$. Activities of a-amylase, protease, and cellulase increased significantly after $48 \mathrm{~h}$ fermentation $(\mathbf{p}<\mathbf{0 . 0 5})$. In addition, amino-type nitrogen and reducing sugar contents in Cheonggukjang fermented with $B$. subtilis increased significantly after $48 \mathrm{~h}$ fermentation $(p<0.05)$. Among the isoflavones, the content of $\beta$-glucosides and acetyl-glucosides decreased, while aglycone content increased during fermentation. Especially, Cheonggukjang fermented with Daepoong cultivars showed the greatest increase in daidzein, genistein and glycitein contents. After $48 \mathrm{~h}$ fermentation, the contents of daidzein, genistein and glycitein in the Cheonggukjang fermented with Daepoong cultivars increased significantly up to $503.65 \pm 2.76,111.40 \pm 0.42$, and $633.95 \pm 6.01 \mu \mathrm{g} / \mathrm{g}(\mathrm{p}<0.05)$, respectively. Total aerobic and anaerobic cell counts increased with increase in fermentation time. Therefore, it would be beneficial for the food industry if components of Cheonggukjang could be separated and used to develop functional products.
\end{abstract}

Key words : soybean, Cheonggukjang, isoflavone, protease

\section{서 론}

콩은 단백질과 지질의 함량이 풍부하여 쌀 중심의 우리 식생활을 보완해주는 식품으로 잘 알려져 있을 뿐만 아니라 생리적 조절 작용에 관여하는 생리활성물질을 다량 함유하 고 있다(1-3). 콩의 가장 특징적인 성분인 isoflavone은 C6-C3-C6를 기본으로 하는 폐놀계 화합물로 여성 호르몬 인 estrogen과 유사한 구조를 가지며(4-6), 여성호르몬 유사

*Corresponding author. E-mail : songjin@korea.kr Phone : 82-63-238-3623, Fax : 82-63-238-3843

Received 17 June 2015; Revised 21 July 2015; Accepted 21 July 2015.

Copyright (c) The Korean Society of Food Preservation. All rights reserved.
작용을 가지기 때문에 식물성 에스트로겐(phytoestrogen)이 라 부른다. Setchell 등(7)에 의하면 이는 혈중 콜레스테롤을 낮추고 심혈관질환, 골다공증을 예방할 뿐만 아니라 폐경 기 이후의 각종 증후군을 완화하고, 유방암, 전립선암, 난소 암, 대장암등의 예방효과 등 이소플라본의 생리적 활성을 보고하였다. 이소플라본은 genistein, daidzein, glycitein의 3 종류의 aglycone과 각각의 배당체인 daidzin, genistin, glycitin 그리고 malnonyl화 배당체, acetyl화 배당체의 12 종 류의 존재가 확인되었다(8). 콩의 isoflavone 함량은 품종, 환경, 재배방법 등에 따라 달라지며, Wang과 Murphy(9)에 의하면 콩의 배아부분에 함량이 높은 것으로 알려져 있다. Setchell 등(10)은 배당체 형태의 이소플라본은 용해도가 비배당체에 비하여 높으나 이소플라본은 nonionic passive 
diffusion 기작에 의하여 흡수되므로 비배당체 형태가 이러 한 흡수 메커니즘에 유리하다고 하였다. 대두에는 $\beta$ -glucosidase가 함유되어 있어 대부분의 대두 가공식품제조 중 행해지는 침지과정에서 이 효소에 의해 genistin이나 daidzin이 가수분해 되어 당이 제거된 aglycone의 함량이 증가한다고 보고되어 있다(11).

청국장은 쉽게 만들어 먹을 수 있는 단백질 발효식품으 로, 영양 가치가 높으며, 소화가 잘 될 뿐만 아니라, 단시간 에 제조하여 쉽게 먹을 수 있는 식품으로 삶은 콩에 Bacillus subtilis를 접종하며 발효과정 중 Bs subtilis 가 생산하는 효소 에 의해서 특유의 맛과 냄새를 내는 동시에 원료 콩에서 유래된 levan form fructan과 polyglutamate의 중합물질인 끈적끈적한 점질물을 생산한다. 청국장의 기능성에 대한 연구로는 Iwai 등(12)에 의해 콜레스테롤 저하, 고혈압방지 효과, 항산화효과, 항균효과와 Seo 등(13)과 $\mathrm{Kim}$ 등(14)에 의해 청국장의 혈전용해 활성과 관련된 많은 연구논문이 발표되었다. 그러나 아직 청국장의 생리활성 기능을 나타 내는 isoflavone aglycone함량을 늘이는데 관련된 연구는 미비한 실정이다.

따라서 본 연구에서는 메밀 속성 장으로부터 분리된 $\beta$ -glucosidase활성이 있는 B. subtilis HJ18-9균을 접종하여 품종별로 청국장을 제조하여 품질특성과 isoflavone 함량을 측정하였다.

\section{재료 및 방법}

\section{재 료}

본 실험에서 사용된 원료콩은 대원콩, 대풍콩, 우람콩, 황금올콩, 새단백콩을 사용하였다. 스타터로 사용된 $B$. subtilis HJ18-9은 Lee 등(15)의 선행연구를 통해 메밀속성 장으로부터 분리된 균으로 amylase, protease, cellulase등의 세포의 효소분비능이 우수한 균이다.

\section{청국장 제조}

콩은 세척하여 실온에서 침지 $\left(25^{\circ} \mathrm{C}, 24 \mathrm{hr}\right)$ 하고 autoclave 를 이용하여 증자 $\left(121^{\circ} \mathrm{C}, 30 \mathrm{~min}\right)$ 하였다. 콩이 $40^{\circ} \mathrm{C}$ 이하로 냉각되었을 때 각 분리균주의 배양액을 접종하여 $37^{\circ} \mathrm{C}$ 에서 $48 \mathrm{hr}$ 발효하여 청국장을 제조하였다. 각 균주를 $10^{6}$ $\mathrm{CFU} / \mathrm{mL}$ 이상의 농도가 되도록 배양하여 시료량의 $1 \%(\mathrm{w} / \mathrm{w})$ 가 되도록 첨가 하였다.

\section{추출물 제조}

청국장 시료 $20 \mathrm{~g}$ 에 $80 \mathrm{~mL}$ 의 증류수를 첨가하고 균질화 한 후 이를 원심분리 $(8,000 \mathrm{rpm}, 10 \mathrm{~min})$ 한 후 상등액을 분석 시료로 사용하였다.

\section{a-Amylase 활성 측정}

a-Amylase 활성 측정은 Yoon(16)이 사용한 DUN (Dextrinogenic Unit of Nagase)방법에 따라 $1 \%$ 전분 기질액 (0.2 M sodium phosphate buffer, $\mathrm{pH} 7.0$ ) $3 \mathrm{~mL}$ 에 시료추출액 $1 \mathrm{~mL}$ 를 넣고 반응 $\left(40^{\circ} \mathrm{C}, 10 \mathrm{~min}\right)$ 시킨 후 반응액 $1 \mathrm{~mL}$ 에 $0.1 \mathrm{M} \mathrm{HCl} 10 \mathrm{~mL}$ 를 넣어 반응을 정지시켰다. 반응을 정지시 킨 용액 $1 \mathrm{~mL}$ 에 $0.005 \% \mathrm{I}_{2}-0.05 \% \mathrm{KI}$ 용액 $10 \mathrm{~mL}$ 를 넣어 발색시킨 후 $660 \mathrm{~nm}$ 에서 흡광도를 측정하였다. 위와 같은 방법으로 측정하여 다음 식에 의해 효소활성을 계산하 였다.

\section{D.U.N $=\left[\left(D^{-D}\right) / D\right] \times 10 / 100 \times \mathbf{n}$ \\ $\mathrm{D}$ : Absorbance of control \\ D' : Absorbance of sample \\ $\mathrm{n}$ : Dilution ratio of sample}

\section{Protease 활성 측정}

Protease 활성 측정은 식품공전(17)에 따라 측정하였다. $0.2 \mathrm{M}$ phosphate buffer에 $0.6 \%$ casein을 용해한 후 $\mathrm{pH}$ 를 7.0 으로 보정하여 기질용액을 제조하였다. 이 기질용액 1.5 $\mathrm{mL}$ 에 시료추출액 $0.5 \mathrm{~mL}$ 를 넣어 반응 $\left(37^{\circ} \mathrm{C}, 10 \mathrm{~min}\right)$ 시킨 후, $0.44 \mathrm{M}$ trichloroacetic acid(TCA) $2 \mathrm{~mL}$ 을 가하여 반응을 정지시켰다. 25 분간 $37^{\circ} \mathrm{C}$ water bath에서 방치시킨 후 여과 (Whatman No. 2)하였다. 여액 $1 \mathrm{~mL}$ 에 $0.55 \mathrm{M} \mathrm{Na}_{2} \mathrm{CO}_{3}$ 용액 $5 \mathrm{~mL}$ 를 첨가한 후, Folin 시약 $1 \mathrm{~mL}$ 를 첨가하여 발색 $\left(37^{\circ} \mathrm{C}\right.$, $20 \mathrm{~min}$ )시켜서 $660 \mathrm{~nm}$ 에서 흡광도를 측정하였다. 반응 후 분해물의 tyrosine 양은 tyrosine 표준곡선으로부터 계산하 였으며, 효소 활성은 시료 $1 \mathrm{~g}$ 에 의해 1 분간 tyrosine $1 \mathrm{\mu g}$ 을 생성하는 능력을 1 unit으로 하였다.

\section{Cellulase 활성 측정}

Cellulase 활성 측정은 carboxymetyl cellulose sodium salt(CMC)를 기질로 하여 효소와 반응 시킨 후, 유리된 환원 당을 3,5-dinitrosalicylic acid acid(DNS) 방법으로 다음과 같 이 측정하였다. $1 \% \mathrm{CMC}(\mathrm{pH} 7.0)$ 용액 $0.5 \mathrm{~mL}$ 와 $0.2 \mathrm{M}$ sodium phosphate buffer(pH 7.0) $0.25 \mathrm{~mL}$ 를 넣은 후, 시료추 출액 $0.25 \mathrm{~mL}$ 을 첨가하여, $50^{\circ} \mathrm{C}$ 에서 15 분간 반응시킨 후, 3,5-dinitrosalicylic acid acid(DNS)를 $3 \mathrm{~mL}$ 가하여 반응을 정지시킨 후, 5 분간 긇는 물에 중탕시켜 발색시킨 다음, $540 \mathrm{~nm}$ 에서 흡광도 측정하였다. 대조구는 반응 정지를 먼 저 시킨 다음, 위와 같은 방법으로 측정하였다. 효소활성을 시료 $1 \mathrm{~g}$ 에 의해 1 분간 glucose $1 \mu \mathrm{g}$ 을 생성하는 능력을 1 unit으로 정의 하였다.

\section{환원당 측정}

환원당은 Chae 등(18)의 방법에 기초한 dinitrosalicylic $\operatorname{acid(DNS)}$ 방법에 의하여 측정하였다. 시료 추출액 $1 \mathrm{~mL}$ 에 
DNS $3 \mathrm{~mL}$ 를 혼합한 후 5 분 동안 중탕가열하고 냉각한 후 $550 \mathrm{~nm}$ 에서 흡광도를 측정하며 glucose standard curve를 통해 환원당 값을 구하였다.

Reducing sugar $(\%)=A \times D \times 1 / S \times 100 / 1000$

A : Reducing sugar content in sample solution (mg)

D : Dilution ratio

$\mathrm{S}$ : Mass of sample $(\mathrm{g})$

\section{아미노태 $\left(\mathrm{NO}^{-}-\mathrm{N}\right)$ 질소 함량 측정}

아미노태 질소 함량은 Weatherburn(19)의 방법에 따라 시료추출액 $5 \mathrm{~mL}$, 중성 formalin 용액 $10 \mathrm{~mL}$, 증류수 10 $\mathrm{mL}$ 를 넣은 플라스크에 $0.5 \%$ phenolphthalein 용액 2 3방울 을 가한 후, $0.1 \mathrm{~N} \mathrm{NaOH}$ 로 미홍색이 될 때까지의 적정양과 시료추출액 $5 \mathrm{~mL}$, 증류수 $20 \mathrm{~mL}$ 을 넣은 플라스크에 $0.5 \%$ phenolphthalein 용액을 2 3방울을 가한 후, $0.1 \mathrm{~N} \mathrm{NaOH}$ 로 미홍색이 될 때까지 적정양을 이용하여 아미노태 질소 함량 을 산출하였다.

Amino type nitrogen $(\%)=(\mathrm{V} 1-\mathrm{V} 0) \times \mathrm{F} \times 0.0014 \times \mathrm{D} \times 100 / \mathrm{S}$

V1 : Titration value of sample $(\mathrm{mL})$

V0 : Titration value of blank treat $(\mathrm{mL})$

F : Facter of $0.1 \mathrm{~N} \mathrm{NaOH}$

D : Dilution ratio

$\mathrm{S}$ : Mass of sample (g)

0.0014 : Nitrogen weight in $1 \mathrm{~mL}$ of $0.1 \mathrm{~N} \mathrm{NaOH}(\mathrm{g})$

\section{암모니아태 $\left(\mathrm{NH}_{4}{ }^{+}-\mathrm{N}\right)$ 질소함량 측정}

암모니아태 질소함량은 아미노태 질소함량 측정 때와 동일한 시료추출액 $0.1 \mathrm{~mL}$ 취한 후 phenol-hypochloride 반 응에 의하여 시료 추출액 $0.1 \mathrm{~mL}$ 에 $\mathrm{A}$ 용액(phenol $10 \mathrm{~g}$ 과 sodium nitroprusside dihydrate $0.05 \mathrm{~g} /$ distilled water $1 \mathrm{~L}$ )과 $\mathrm{B}$ 용액 $\left(\mathrm{Na}_{2} \mathrm{HPO}_{4} \cdot 12 \mathrm{H}_{2} \mathrm{O} 9 \mathrm{~g}, \mathrm{NaOH} 6 \mathrm{~g}\right.$ 과 $\mathrm{NaOCl} 10$ $\mathrm{mL} /$ distilled water $1 \mathrm{~L}$ )을 각각 $2 \mathrm{~mL}$ 씩 넣고 $37^{\circ} \mathrm{C}$ 에서 20 분 간 반응시켜 $630 \mathrm{~nm}$ 에서 흡광도를 측정하였으며, 표준곡선 은 $\left(\mathrm{NH}_{4}\right)_{2} \mathrm{SO}_{4}$ 를 사용하여 암모니아태 질소함량을 측정하 였다(20).

\section{호기적 균 및 혐기적 균 측정}

청국장 시료를 10 배 단계 희석한 후, 호기적 균수는 plate count agar(Difco ${ }^{\mathrm{TM}}$, Laboratories, USA)에 호기 조건에서 $37^{\circ} \mathrm{C}, 24$ 시간 동안 배양하였으며, 혐기성 총균수는 MRS agar(Difco Laboratories, Detroit, MI, USA)를 이용하여 혐기 조건에서 $37^{\circ} \mathrm{C}, 48$ 시간 동안 배양하여 계수하였다.

\section{Isoflavone 분석}

Isoflavone 분석은 Wang 등(21)의 방법을 사용하였다. 청 국장은 동결건조 시킨 후 분쇄하여 $40 \mathrm{mesh}$ sieve를 통과시 켜 분말로 제조하고, 동결건조 분말 $2 \mathrm{~g}$ 에 acetonitrile 24 $\mathrm{mL}$ 과 $1 \mathrm{~mol} \mathrm{HCl} 6 \mathrm{~mL}$ 로 실온에서 1 시간 추출하였으며 filtration(Whatman No. 2) 시켜 3차 증류수로 2 배 희석 하여 $0.2 \mu \mathrm{M}$ membrane filter로 filtration시켜 UPLC(Waters, MA, USA)로 분석하였다. UPLC는 Waters Acquity system을 사 용하였으며, column은 Acquity UPLC $\mathbb{R} H S S$ C18 1.8 um $\times 2.1 \times 75 \mathrm{~mm}$ column, 이동상은 $0.1 \%$ acetic acid를 함유 한 $10 \% \mathrm{MeOH}$ (용매A)와 $0.1 \%$ acetic acid를 함유한 $\mathrm{MeOH}$ (용매B)을 사용하였다. 용매 gradient는 용매 $\mathrm{B}$ 의 농도를 17 분간 $26 \%$ 에서 $50 \%$ 로 증가시켰고, 유속은 $0.3 \mathrm{~mL} / \mathrm{min}$, injection volume은 $0.8 \mu \mathrm{L}, \mathrm{UV}$ detector파장은 $254 \mathrm{~nm}$ 로 분석하였다.

\section{통계처리}

본 실험에서 얻어진 결과의 통계처리는 SPSS program (12.0, SPSS Inc. Chicago, IL, USA)을 이용하여 실시하였으 며, 각 항목에 대한 평균(mean) 및 표준편차(standard deviation, $\mathrm{SD}$ )를 산출하였다. 각 청국장간 차이는 $\mathrm{p}<0.05$ 수준에서 one-way ANOVA를 실시하였으며, Duncan's multiple range test로 그 유의성을 검증하였다.

\section{결과 및 고찰}

\section{a-Amylase}

전분을 분해하는 효소인 a-amylase 활성은 Table 1과 같 다. 5품종 모두 발효 초기보다 48시간 발효 후에 효소활성이

Table 1. Changes in enzyme activities during Chungkookjang fermentation by using the five different soybean cultrivars

\begin{tabular}{ccccccc}
\hline Enzyme & Fermentation time (hr) & Daewon & Daepoong & Wooram & Hwangkeumol & Saedanback \\
\hline a-Amylase (U/g) & 0 & $0.00 \pm 0.00^{1)}$ ns & $2.14 \pm 1.24$ & $7.50 \pm 12.98$ & $0.90 \pm 0.24$ & $0.00 \pm 0.00$ \\
& 48 & $33.33 \pm 0.10^{\mathrm{e}}$ & $40.72 \pm 0.46^{\mathrm{b}}$ & $37.25 \pm 0.26^{\mathrm{d}}$ & $39.04 \pm 0.29^{\mathrm{c}}$ & $42.54 \pm 0.08^{\mathrm{a}}$ \\
& 0 & $125.37 \pm 5.66^{\mathrm{ab}}$ & $122.00 \pm 2.50^{\mathrm{ab}}$ & $128.27 \pm 11.14^{\mathrm{ab}}$ & $114.10 \pm 15.52^{\mathrm{b}}$ & $134.53 \pm 7.62^{\mathrm{a}}$ \\
Protease (U/g) & 48 & $195.33 \pm 11.61^{\mathrm{bc}}$ & $235.33 \pm 4.02^{\mathrm{a}}$ & $243.67 \pm 6.17^{\mathrm{a}}$ & $179.92 \pm 12.52^{\mathrm{c}}$ & $197.42 \pm 7.64^{\mathrm{b}}$ \\
& 0 & $9.45 \pm 2.55^{\mathrm{ab}}$ & $10.56 \pm 5.09^{\mathrm{ab}}$ & $12.78 \pm 1.92^{\mathrm{a}}$ & $8.34 \pm 2.89^{\mathrm{ab}}$ & $4.45 \pm 2.55^{\mathrm{b}}$ \\
Cellulase (U/g) & 48 & $601.11 \pm 37.46^{\mathrm{b}}$ & $566.67 \pm 4.41^{\mathrm{bc}}$ & $646.67 \pm 18.78^{\mathrm{a}}$ & $478.33 \pm 20.48^{\mathrm{d}}$ & $526.67 \pm 18.03^{\mathrm{c}}$ \\
\hline
\end{tabular}

\footnotetext{
${ }^{1)}$ Means in the same row followed by different letters are significantly different $(\mathrm{p}<0.05)$.
} 
증가하는 경향을 보였으며, 새단백콩으로 제조한 청국장의 효소활성이 $42.54 \pm 0.08$ unit/g으로 유의적으로 가장 높은 효소활성을 보였다.

a-Amylase활성은 환원당을 유리하는데 관여하여 단맛 에 영향을 주는 요인이다. 품종별로 제조된 청국장의 $a$ -amylase 활성도는 대부분 비슷한 경향을 나타냈으며 48시 간 발효 후에는 $33.33 \pm 0.10 \sim 42.54 \pm 0.08$ units $/ \mathrm{g}$ 의 범위를 나타내었다.

일반적으로 된장의 경우 a-amylase 활성은 담금 초기에 높았다가 발효가 진행되면서 서서히 낮아진다고 보고되었 으며(22), 이는 원료에 함유되어 있던 탄수화물이 a-amylase 의 기질이 되어 효소 활성이 높았다가 전분질 기질이 고갈 되어 감에 따라 점차 활성이 낮아지게 된다. Lee 등(23)은 발효시간과 온도별로 a-amylase 활성이 다르게 나오는 결과 를 보고하였으며, 같은 품종에서도 발효조건에 따라 다른 효소활성을 나타낸다고 하였다. 본 연구에 사용된 청국장 의 품종에 따른 차이로 인해, 발효시간이 경과함에 따라 a-amylase 활성이 감소되는 시점이 다른 것으로 사료된다.

\section{Protease}

품종을 달리하여 제조한 청국장의 protease 효소활성은 Table 1 에 나타내었다. Protease는 단백질 또는 peptide에 작용하여 peptide bond의 가수분해를 촉매하는 효소로 동. 식물, 미생물의 조직이나 세포조직 중에 존재한다. 5 품종 모두 발효 초기보다 48시간 발효 후에 효소활성이 증가하 는 경향을 보였으며, 발효초기에는 새단백콩으로 제조한 청국장의 효소활성이 $134.53 \pm 7.62 \mathrm{unit} / \mathrm{g}$ 으로 유의적으로 가장 높은 효소활성을 보였으나, 48시간 후에는 우람콩으 로 제조한 청국장이 $243.67 \pm 6.17$ unit/g으로 가장 높은 효소 활성을 보였다.

$\operatorname{Ann}(24)$ 은 청국장의 단백질가수분해효소 활성이 발효 36 시간에 가장 높았으며, 이후 점차 낮아졌다고 보고하였 다. Youn 등(25)은 청국장의 protease활성은 발효 5 10시간 이후부터 증가하기 시작하여 35 40시간 이후에는 거의 최 대 활성에 도달 하였는데 이는 48시간 동안 발효한 본 실험
에서 가장 높은 활성을 기대할 수 있을 것으로 사료된다.

$\operatorname{Kim}(26)$ 은 protease 활성은 청국장 단백질 분해 특유의 구수한맛 성분을 유리하고 유리아미노산함량에 많은 영향 을 주는 요인으로서 맛에서 구수함과 연관성을 가지는 아미 노태 질소만으로 콩 품종별 청국장을 비교해 볼 때 높은 소립류인 원광콩이 청국장에 적합할 것으로 판단된다고 하였다.

\section{Cellulase}

품종을 달리하여 제조한 청국장의 cellulase 효소활성은 Table 1 과 같다. 전통 장류인 된장이나 간장은 발효과정에 서 미생물의 다양한 효소에 의해 콩에 함유된 단백질, 올리 고다당류, 이소플라본, 지질 등이 소화되기 쉬운 형태의 아미노산, 유리당, 이소플라본 아글리콘, 지방산 등으로 분 해되어 항산화 및 혈전용해 기능을 갖는 2 차산물이 생성된 다고 하였다(27-29). Cellulase중 특히 CMCase(carboxymethyl cellulase, Endo $\beta-1,4$-glucanase)는 exo- $\beta-1,4$-glucanase)는 exo- $\beta$-glucanase, $\beta$-glucanase와 함께 cellulase계 구성효소 로서 식물세포벽 구성성분 중 대부분 차지하고 있는 cellulose을 분해할 수 있는 능력을 가지고 있어 장내 이용성 증진을 위해 널리 사용되는 효소이다. 그러나 아직 전통장 류인 청국장에서 cellulase 활성에 대한 연구는 미비한 시점 이다. 따라서 본 실험에서는 B. subtilis $\mathrm{HJ} 18-9$ 균을 청국장 의 starter로 사용하였을 때 다양한 품종별 청국장에서 cellulase 활성을 측정하였다. 본 실험에서는 Table 1 의 결과 와 같이 5 품종 모두 발효 초기보다 48시간 발효 후에 효소활 성이 증가하는 경향을 보였으며, protease 활성과 마찬가지 로 우람콩으로 제조한 청국장의 효소활성이 발효초기와 발효 후에도 가장 높은 효소활성을 보였다.

\section{아미노태 질소}

품종을 달리하여 제조한 청국장의 아미노태질소함량은 Table 2에 나타내었다. Mann 등(30)에 의하면 일반적으로 아미노태 질소 함량은 protease의 작용에 의하여 단백질이 아미노산의 형태로 분해되는 정도를 나타낸 것으로 청국장

Table 2. Changes in amino-type nitrogen, ammonia-type nitrogen and reducing sugar contents during Chungkookjang fermentation by using the five different soybean cultrivars

\begin{tabular}{ccccccc}
\hline Type & $\begin{array}{c}\text { Fermentation } \\
\text { time (hr) }\end{array}$ & Daewon & Daepoong & Wooram & Hwangkeumol & Saedanback \\
\hline \multirow{2}{*}{ Amino-type nitrogen (mg\%) } & 0 & $58.80 \pm 2.42^{1) \mathrm{a}}$ & $45.27 \pm 0.81^{\mathrm{b}}$ & $42.00 \pm 1.40^{\mathrm{b}}$ & $44.33 \pm 2.14^{\mathrm{b}}$ & $60.20 \pm 1.40^{\mathrm{a}}$ \\
& 48 & $72.78 \pm 1.40^{\mathrm{c}}$ & $98.47 \pm 1.62^{\mathrm{b}}$ & $112.46 \pm 1.62^{\mathrm{a}}$ & $57.39 \pm 2.80^{\mathrm{d}}$ & $101.27 \pm 0.81^{\mathrm{b}}$ \\
Ammonia-type nitrogen (mg\%) & 0 & $61.90 \pm 2.98^{\mathrm{a}}$ & $47.35 \pm 3.86^{\mathrm{c}}$ & $43.01 \pm 1.47^{\mathrm{c}}$ & $44.53 \pm 1.47^{\mathrm{c}}$ & $55.28 \pm 1.22^{\mathrm{ab}}$ \\
& 48 & $62.65 \pm 1.47^{\mathrm{d}}$ & $127.10 \pm 0.97^{\mathrm{b}}$ & $68.87 \pm 1.32^{\mathrm{c}}$ & $65.59 \pm 3.21^{\mathrm{cd}}$ & $161.24 \pm 4.62^{\mathrm{a}}$ \\
Reducing sugar (\%) & 0 & $0.41 \pm 0.00 \mathrm{~ns}$ & $0.40 \pm 0.00$ & $0.41 \pm 0.00$ & $0.42 \pm 0.03$ & $0.42 \pm 0.04$ \\
& 48 & $0.55 \pm 0.17 \mathrm{~ns}$ & $0.28 \pm 0.12$ & $0.45 \pm 0.15$ & $0.29 \pm 0.13$ & $0.30 \pm 0.11$ \\
\hline
\end{tabular}

${ }^{1)}$ Means in the same row followed by different letters are significantly different $(\mathrm{p}<0.05)$. 
의 발효도 평가 및 장류 발효식품의 품질과 구수한 맛의 지표로 사용되고 있다. 아미노태 질소 함량은 protease 활성 과 유사한 경향을 나타내는데 본 연구에서도 유사한 경향을 확인할 수 있었다. 청국장의 발효과정 중에 생성되는 점질 물은 원료콩의 당질과 단백질에서 유래된 levan form fructan과 polyglutamate의 중합체이다. Kim 등(31)은 콩 단 백질 분해산물인 질소성분의 일부는 아미노태, 암모니아태 질소로 전환되고, 나머지는 polyglutamate 대사에 이용되어 지는 것으로 보고되고 있다고 하였다. 또한 아미노태 질소 함량이 발효온도가 $30^{\circ} \mathrm{C}$ 일 때 가장 높았으며, $35^{\circ} \mathrm{C}, 40^{\circ} \mathrm{C}$, $45^{\circ} \mathrm{C}$ 순으로 감소하는 결과를 나타낸다고 하였다. Kim 등 (32)은 작은콩을 이용하여 제조된 청국장의 아미노태 질소 함량이 가장 높았으며, 검은 콩에서 가장 낮게 나타났다고 보고하였다. Hwang(33)은 발효시간 경과에 따라 아미노태 질소함량이 증가하였으며, $30^{\circ} \mathrm{C}$ 가 $45^{\circ} \mathrm{C}$ 보다 아미노태 질소 함량이 더 높게 나타났다고 하였다.

본 실험에서 발효초기에 가장 높은 protease 활성을 보였 던 새단백의 아미노태질소 함량이 $60.20 \pm 1.40 \mathrm{mg} \%$ 으로 다른 품종에 비해 높게 나타났으며, 48시간 후에는 마찬가 지로 protease활성을 높은 우람콩으로 제조한 콩의 아미노 태 질소함량이 $112.46 \pm 1.62 \mathrm{mg} \%$ 로 가장 높게 나타났다. Youn 등(25)과 Zheng 등(34)은 이 제조한 청국장의 아미노 태 질소 함량이 각각 $112 \mathrm{mg} \%$ 224 mg\%, 264 422 mg\%라 고 보고 하였는데, 본 연구의 결과는 이러한 결과에 다소 미치지 못하는 것으로 나타났다. 본 연구에서 전체적으로 아미노태 함량이 낮은 것은 발효시간이나 온도와 같은 환경 과 사용한 균주, 품종에 의한 영향인 것으로 사료된다.

\section{암모니아태 질소}

본 실험의 암모니아태 질소함량은 발효 초기에는 $43.01 \pm 1.47 \sim 61.90 \pm 2.98 \mathrm{mg} \%$ 로 나타났으며 48시간 발효 후 에는 품종별로 그 값이 차이가 많았으며, 새단백 청국장이 $161.24 \pm 4.62 \mathrm{mg} \%$ 로 높은 값을 나타냈다(Table 2). Hwang 등(35)의 보고에서 발효 기간 중 주로 미생물이 분비하는 protease가 원료대두의 단백질에 작용하여 수용성 질소형 태로 가수분해 되고 이어서 peptide를 거쳐 아미노태 질소 형태로 가수분해 하여 청국장의 구수한 맛이 생성됨과 동시 에 발효가 계속 진행되면서 암모니아태 질소를 형성시킨다 고 하였다. 암모니아태 질소는 단백질 분해과정에서 deamination에 의하여 생성되며 식품 내에 과량으로 축척되 면 부패취로 작용하므로 일반적으로 장류 제품의 변패 또는 이상발효의 지표로 사용된다. 따라서 단백질이 분해되어 아미노태 질소 함량이 증가되는 것은 바람직하나 그 이상의 분해가 진행되어 암모니아태 질소함량이 증가되는 것은 조절할 필요가 있다고 판단된다.

$\mathrm{Ju}$ 와 Ohe(36)는 암모니아태 질소를 감소시키기 위해 $B$. subtilis와 Lactobacillus plantarum를 혼합배양 해여 청국장
의 불쾌취를 감소시켰다고 보고 하였다. 우람콩으로 제조 한 청국장이 아미노태 함량의 높아 구수한 맛을 내고 암모 니아태 함량은 낮은 것으로 나와 불쾌취를 적게 발생시킨 결과로 생각되며, 고품질의 장류 제조 할 수 있을것으로 사료된다.

\section{환원당 함량}

Glucose, fructose, maltose 등의 환원당류들은 단맛을 부 여하는 물질로 식품의 관능적인 품질 평가면에서 대단히 중요하며 이러한 환원당류들은 미생물의 대사에 따른 효소 력 변화와 밀접한 관계가 있어 미생물이 glucose 대사에 이용하는 정도에 따라 환원당 변화가 생긴다. Lee 등(23)은 청국장 발효과정 중, 콩의 전분은 Bacillus 등이 분비하는 효소의 작용으로 가수 분해되어 청국장 단맛 성분의 주체인 당류가 생성된다고 하였다. 발효 10 시간째까지는 환원당의 함량이 급격하게 증가하였으나 그 이후부터 정도의 차이는 있지만 약간 감소하는 경향을 나타내었다. Shon(37)은 여러 종류의 발효 균주를 첨가하여 청국장을 제조할 때 발효 24시간째까지 환원당의 함량이 지속적으로 증가하는 것으 로 보고하였다. 이와 같은 결과는 청국장의 발효가 왕성하 게 시작되면서 발효초기에는 청국장 중에 환원당을 축적하 지만 발효후기에는 발효균주가 환원당을 소비하기 때문인 것으로 추측된다.

$\mathrm{Kim}$ 등(38)은 전통장류 제조업체에서 수집한 제품 18점 의 환원당을 분석한 결과 $0.24 ~ 0.51 \%$ 의 범위를 나타낸다 고 보고하였는데, 본 실험과 같은 경향을 보였다(Table 2). 그러나 품종 간에는 유의적 차이는 나타나지 않았다. 본 연구에서 발효시간은 48 시간으로 발효시간을 24 시간으로 하였을 때 더 높은 환원당 값을 기대할 수 있을 것으로 사료된다.

\section{총 균수의 변화}

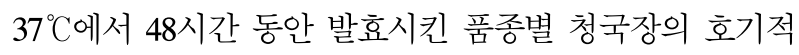
총 균수는 Fig. 1에 나타내었다.

본 실험결과 대체적으로 발효초기보다 발효 후에 총 균 수가 높아지는 경향을 보였으며 발효 초에는 우람콩 청국장 이 유의적으로 높은 균수를 보였으나, 발효 후에는 품종 간에 유의적인 차이는 보이지 않았다. Oh와 $\operatorname{Eom}(39)$ 은 발 효 21시간 이후에 청국장에서 $8.9 \log \mathrm{CFU} / \mathrm{g}$ 수준으로 미생 물이 생육하였다고 보고하여 본 실험결과와 유사하였다. Baek 등(40)은 발효 24시간 이후 각 처리구의 총균수는 $10^{9} \mathrm{CFU} / \mathrm{mL}$ 이상을 나타낸다고 하였으며, Youn 등(25)은 B. natto와 B. licheniformis를 이용하여 청국장을 제조하였 을 때 청국장발효 40 시간 이후 총균수는 $10^{9} \mathrm{CFU} / \mathrm{mL}$ 이었 다고 보고하였으나 본 실험의 결과와는 조금 차이가 있었 다. 이러한 결과는 스타터로 사용한 B. subtilis HJ18-9 균주 가 Lee 등(15)의 선행연구 결과 Salmonella enterica, 
Staphylococcus aureus, Candida albicans에 대해 항균력이 우수하다고 함에 따라 B. subtilis HJ18-9의 뛰어난 항균성에 의한 것으로 생각된다.

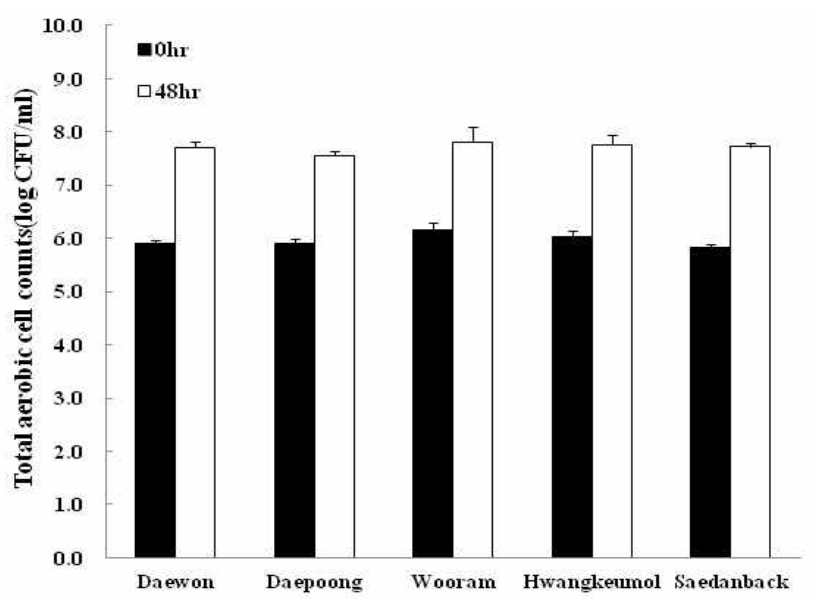

Fig. 1. Changes in total aerobic cell counts during Chungkookjang fermentation by using the five different soybean cultrivars.

\section{Isoflavone 함량 변화}

$37^{\circ} \mathrm{C}$ 에서 48 시간 동안 발효시킨 청국장의 isoflavone함량 과 chromatogram은 Fig. 2와 Table 3에 나타내었다. 발효초 기에는 대풍 청국장과 우람콩 청국장이 $235.23 \pm 3.22$, $304.24 \pm 11.56$ 으로 높은 aglycone함량을 보였으며, 발효 후 에도 두가지 품종이 유의적으로 높은 aglycone함량을 보였 다. 발효 초에 비하여 발효 후에는 1.66 5.31배 높은 전환율 을 보였다. Jung 등(41)은 청국장의 총 isoflavone 함량이 발아 및 발효시간에 따라 다른 경향을 나타내는 것은 원료 대두의 품종, 발아 및 발효조건, 발효균주 등이 다르기 때문 인 것으로 생각된다고 하였는데, 본 연구에서는 청국장 발 효에 사용되는 다양한 품종에 의해서 isoflavone함량이 차 이가 나타난 것으로 사료된다. 또한 $\mathrm{Bae}$ 등(42)은 대두 isoflavone은 동일품종의 경우 재배위치나 재배년도에 따라 함량이 46 195 mg/g정도로 차가 있다고 보고되어 있다고 하였다. Shon 등(43)은 대립 검정콩의 경우 daidzein과 genistein의 총 함량이 처음에 $779.92 \mu \mathrm{g} / \mathrm{g}$ 이었던 것이 발효 3 일 후에는 $1278.04 \mathrm{ug} / \mathrm{g}$ 으로 증가하였으며, 소립검정콩의
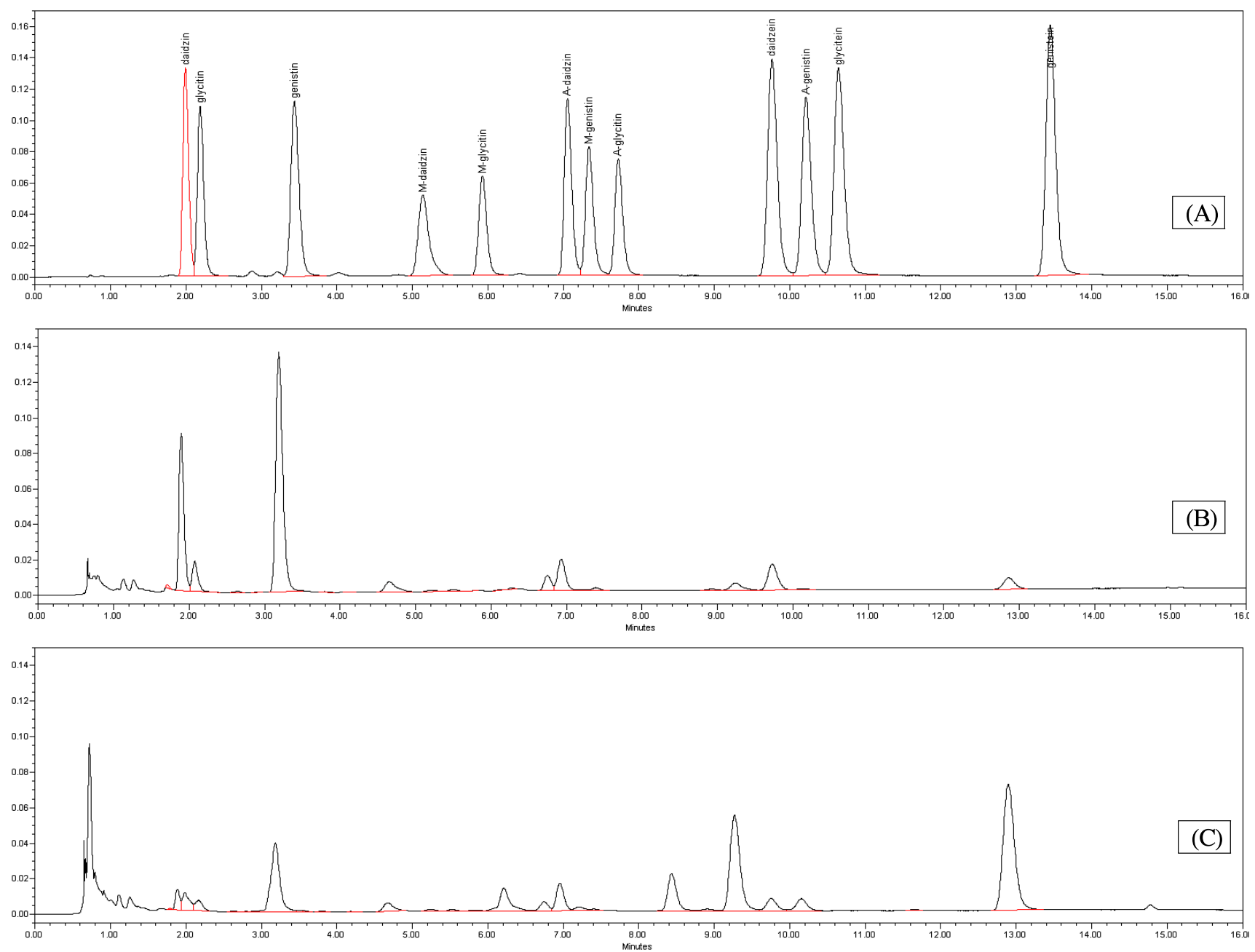

Fig. 2. Chromatogram of isoflavone standard (A), $0 \mathrm{hr}$ (B) and $48 \mathrm{hr}$ (C). 
Table 3. Changes in isoflavone contents $(\mu \mathrm{g} / \mathrm{g}$ dry matter) during Chungkookjang fermentation by the five different soybean cultrivars

(ug/g)

\begin{tabular}{|c|c|c|c|c|c|c|}
\hline & Fermentation time (hr) & Daewon & Daepoong & Wooram & Hwangkeumol & Saedanback \\
\hline \multirow[t]{2}{*}{ daidzin } & 0 & $598.10 \pm 0.28^{1) c}$ & $716.25 \pm 7.00^{b}$ & $734.95 \pm 6.86^{\mathrm{a}}$ & $203.20 \pm 2.12^{\mathrm{e}}$ & $320.70 \pm 0.99^{d}$ \\
\hline & 48 & $274.80 \pm 0.71^{\mathrm{b}}$ & $116.20 \pm 0.28 \mathrm{c}$ & $538.10 \pm 3.82^{\mathrm{a}}$ & $55.80 \pm 0.28^{\mathrm{e}}$ & $83.05 \pm 0.78^{d}$ \\
\hline \multirow[t]{2}{*}{ glycitin } & 0 & $161.20 \pm 1.41^{\mathrm{c}}$ & $211.10 \pm 1.98^{\mathrm{a}}$ & $173.50 \pm 4.67^{\mathrm{b}}$ & $117.00 \pm 1.13^{\mathrm{d}}$ & $121.50 \pm 3.39^{\mathrm{d}}$ \\
\hline & 48 & $146.40 \pm 2.12^{c}$ & $167.10 \pm 0.57^{b}$ & $143.30 \pm 3.54^{\mathrm{c}}$ & $105.20 \pm 4.38^{\mathrm{d}}$ & $175.30 \pm 1.56^{\mathrm{a}}$ \\
\hline \multirow[t]{2}{*}{ genistin } & 0 & $995.20 \pm 7.35^{b}$ & $1300.00 \pm 21.78^{\mathrm{a}}$ & $1023.55 \pm 26.38^{\mathrm{b}}$ & $301.10 \pm 10.04^{d}$ & $427.70 \pm 3.54^{c}$ \\
\hline & 48 & $727.10 \pm 0.85^{\mathrm{a}}$ & $499.75 \pm 17.04^{b}$ & $781.75 \pm 92.56^{\mathrm{a}}$ & $175.85 \pm 6.86^{d}$ & $307.70 \pm 4.10^{\mathrm{c}}$ \\
\hline \multirow[t]{2}{*}{$\beta$-glucoside } & 0 & $1754.50 \pm 5.66^{\mathrm{c}}$ & $2227.35 \pm 30.76^{\mathrm{a}}$ & $1932.05 \pm 28.50^{\mathrm{b}}$ & $621.30 \pm 13.29^{e}$ & $869.90 \pm 0.85^{\mathrm{d}}$ \\
\hline & 48 & $1148.35 \pm .49^{b}$ & $783.05 \pm 16.19^{c}$ & $1463.10 \pm 92.21^{\mathrm{a}}$ & $336.75 \pm 11.53^{\mathrm{e}}$ & $566.05 \pm 6.43^{d}$ \\
\hline \multirow[t]{2}{*}{ M-daidzin } & 0 & $83.85 \pm 0.35^{\mathrm{d}}$ & $162.60 \pm 0.99^{\mathrm{a}}$ & $114.70 \pm 2.69^{b}$ & $69.40 \pm 2.83^{\mathrm{e}}$ & $102.00 \pm 0.71^{\mathrm{c}}$ \\
\hline & 48 & $81.25 \pm 0.49^{c}$ & $137.05 \pm 0.92^{\mathrm{a}}$ & $97.95 \pm 0.49^{b}$ & $66.05 \pm 0.07^{\mathrm{d}}$ & $95.00 \pm 3.11^{\mathrm{b}}$ \\
\hline \multirow[t]{2}{*}{ M-glycitin } & 0 & $62.80 \pm 0.42^{\mathrm{d}}$ & $78.40 \pm 0.85^{\mathrm{a}}$ & $68.10 \pm 1.27^{b}$ & $65.60 \pm 0.71^{\mathrm{c}}$ & $69.40 \pm 0.57^{b}$ \\
\hline & 48 & $75.95 \pm 1.20^{\mathrm{a}}$ & $75.90 \pm 0.57^{\mathrm{a}}$ & $67.15 \pm 1.48^{\mathrm{b}}$ & $61.70 \pm 0.99^{c}$ & $66.50 \pm 0.99^{b}$ \\
\hline \multirow[t]{2}{*}{ M-genistin } & 0 & $121.25 \pm 0.78^{b}$ & $120.10 \pm 1.84^{b}$ & $129.45 \pm 5.44^{\mathrm{a}}$ & $59.85 \pm 0.64^{d}$ & $73.60 \pm 0.14^{\mathrm{c}}$ \\
\hline & 48 & $99.70 \pm 0.71^{\mathrm{a}}$ & $98.75 \pm 0.07^{\mathrm{a}}$ & $92.60 \pm 3.25^{\mathrm{b}}$ & $58.35 \pm 0.92^{d}$ & $69.65 \pm 0.49^{c}$ \\
\hline \multirow[t]{2}{*}{ M-glucoside } & 0 & $267.90 \pm 0.71^{\mathrm{c}}$ & $361.10 \pm 3.68^{\mathrm{a}}$ & $312.25 \pm 9.40^{\mathrm{b}}$ & $194.85 \pm 4.17^{\mathrm{e}}$ & $244.95 \pm 0.07^{\mathrm{d}}$ \\
\hline & 48 & $256.90 \pm 2.40^{\mathrm{b}}$ & $311.65 \pm 1.48^{\mathrm{a}}$ & $257.70 \pm 4.24^{b}$ & $186.10 \pm 1.98^{\mathrm{d}}$ & $231.15 \pm 4.60^{c}$ \\
\hline \multirow[t]{2}{*}{ A-daidzin } & 0 & $111.10 \pm 0.57^{\mathrm{c}}$ & $246.50 \pm 9.05^{\mathrm{a}}$ & $147.05 \pm 7.42^{\mathrm{b}}$ & $85.15 \pm 1.77^{\mathrm{d}}$ & $119.85 \pm 1.06^{c}$ \\
\hline & 48 & $111.45 \pm 0.35^{\mathrm{c}}$ & $227.35 \pm 1.06^{\mathrm{a}}$ & $133.75 \pm 5.30^{\mathrm{b}}$ & $85.15 \pm 2.19^{\mathrm{d}}$ & $127.90 \pm 1.98^{b}$ \\
\hline \multirow[t]{2}{*}{ A-glycitin } & 0 & $176.25 \pm 0.35^{\mathrm{b}}$ & $188.20 \pm 4.38^{\mathrm{a}}$ & $165.10 \pm 6.79^{c}$ & $72.50 \pm 1.70^{\mathrm{e}}$ & $83.85 \pm 2.76^{d}$ \\
\hline & 48 & $130.00 \pm 0.99^{\mathrm{a}}$ & $120.15 \pm 0.78^{b}$ & $116.60 \pm 0.85^{\mathrm{c}}$ & $60.05 \pm 0.78^{\mathrm{e}}$ & $74.30 \pm 1.56^{d}$ \\
\hline \multirow[t]{2}{*}{ A-genistin } & 0 & $63.10 \pm 0.00^{\mathrm{a}}$ & $68.55 \pm 4.60^{\mathrm{a}}$ & $66.25 \pm 2.62^{\mathrm{a}}$ & $54.75 \pm 1.20^{\mathrm{b}}$ & $55.00 \pm 1.13^{\mathrm{b}}$ \\
\hline & 48 & $57.10 \pm 0.28^{\mathrm{ab}}$ & $58.95 \pm 0.64^{\mathrm{a}}$ & $56.45 \pm 0.64^{\mathrm{b}}$ & $48.20 \pm 0.42^{\mathrm{d}}$ & $54.05 \pm 1.77^{\mathrm{c}}$ \\
\hline \multirow[t]{2}{*}{ A-glucoside } & 0 & $350.42 \pm 0.97^{\mathrm{b}}$ & $503.20 \pm 18.06^{\mathrm{a}}$ & $378.45 \pm 6.83^{\mathrm{b}}$ & $212.39 \pm 4.66^{d}$ & $258.72 \pm 5.01^{\mathrm{c}}$ \\
\hline & 48 & $298.55 \pm 1.66^{c}$ & $406.49 \pm 2.44^{\mathrm{b}}$ & $306.80 \pm 6.73^{\mathrm{a}}$ & $193.42 \pm 3.47^{\mathrm{d}}$ & $256.22 \pm 1.71^{\mathrm{d}}$ \\
\hline \multirow[t]{2}{*}{ daidzein } & 0 & $69.45 \pm 0.07^{\mathrm{c}}$ & $83.75 \pm 0.49^{b}$ & $116.10 \pm 4.38^{\mathrm{a}}$ & $49.20 \pm 0.14^{\mathrm{d}}$ & $48.70 \pm 0.71^{d}$ \\
\hline & 48 & $192.05 \pm 0.21^{\mathrm{c}}$ & $503.65 \pm 2.76^{\mathrm{a}}$ & $272.55 \pm 6.72^{b}$ & $103.75 \pm 4.88^{\mathrm{e}}$ & $154.10 \pm 6.79^{d}$ \\
\hline \multirow[t]{2}{*}{ glycitein } & 0 & $53.60 \pm 0.99^{\mathrm{ab}}$ & $53.95 \pm 1.77^{\mathrm{ab}}$ & $56.60 \pm 0.71^{\mathrm{a}}$ & $51.25 \pm 0.78^{\mathrm{bc}}$ & $50.20 \pm 1.41^{\mathrm{c}}$ \\
\hline & 48 & $55.50 \pm 0.28^{\mathrm{c}}$ & $111.40 \pm 0.42^{\mathrm{a}}$ & $61.85 \pm 0.64^{\mathrm{b}}$ & $56.75 \pm 0.78^{\mathrm{c}}$ & $57.55 \pm 1.34^{\mathrm{c}}$ \\
\hline \multirow[t]{2}{*}{ genistein } & 0 & $77.50 \pm 0.14^{\mathrm{c}}$ & $97.55 \pm 0.92^{b}$ & $131.50 \pm 6.51^{\mathrm{a}}$ & $54.15 \pm 0.35^{\mathrm{d}}$ & $52.60 \pm 0.71^{\mathrm{d}}$ \\
\hline & 48 & $185.30 \pm 0.57^{\mathrm{c}}$ & $633.95 \pm 6.01^{\mathrm{a}}$ & $254.90 \pm 8.06^{\mathrm{b}}$ & $96.25 \pm 6.72^{\mathrm{e}}$ & $127.40 \pm 6.22^{\mathrm{d}}$ \\
\hline \multirow[t]{2}{*}{ aglycone } & 0 & $200.52 \pm 0.75^{b}$ & $235.23 \pm 3.22^{\mathrm{a}}$ & $304.24 \pm 11.56^{b}$ & $154.65 \pm 0.31^{d}$ & $151.51 \pm 2.91^{\mathrm{c}}$ \\
\hline & 48 & $432.93 \pm 0.63^{c}$ & $1249.03 \pm 9.14^{\mathrm{a}}$ & $589.32 \pm 14.08^{\mathrm{b}}$ & $256.76 \pm 12.37^{e}$ & $339.04 \pm 14.38^{\mathrm{d}}$ \\
\hline \multirow[t]{2}{*}{ total } & 0 & $2573.35 \pm 6.58^{\mathrm{c}}$ & $3326.90 \pm 55.72^{\mathrm{a}}$ & $2927.00 \pm 66.33^{b}$ & $1183.20 \pm 21.78^{\mathrm{e}}$ & $1525.10 \pm 6.93^{\mathrm{d}}$ \\
\hline & 48 & $2136.75 \pm 4.31^{\mathrm{c}}$ & $2750.25 \pm 26.23^{\mathrm{a}}$ & $2616.95 \pm 67.25^{b}$ & $973.05 \pm 29.34^{e}$ & $1392.45 \pm 27.22^{\mathrm{d}}$ \\
\hline
\end{tabular}

${ }^{1)}$ Means in the same row followed by different letters are significantly different $(\mathrm{p}<0.05)$.

경우는 처음에 $582.56 \mu \mathrm{g} / \mathrm{g}$ 이었던 것이 발효 3 일 후에는 $907.85 \mathrm{\mu g} / \mathrm{g}$ 로 증가되었는데, 이는 발효과정 중 daidzein과 genistein을 함유한 배당체 isoflavone류들의 당류 부분이 분해된 결과라고 보고하였다

$\operatorname{Kim}(26)$ 에 의하면 배당체 형태의 isoflavone은 경구로 섭취된 후 당이 제거되어 aglycone형태로 체내에서 흡수되
거나, 장내 미생물에 의해 파괴되기 때문에 aglycone형태로 섭취할 시에는 더 높은 생리활성을 나타낼 것으로 보고하였 다. 앞에서 언급한 바와 같이 대두의 isoflavone은 glycosided conjugate(malnonylglycoside, $\beta$-glycosides 및 acetylglycosides 형태의 isoflavone isomer와 aglycone 형태로 존재 하는데 대두의 수침이나 가열 등의 가공처리를 하면 용출된 $\beta$ 
-glycosidase의 작용에 의해 aglycone으로 전환되는 것으로 알려져 있다. 따라서 $\beta$-glucosidase 활성이 있는 균주를 첨 가하여 발효함으로써 alycone 전환율을 높이고 품종별로 처리하여, 각 품종별 청국장의 aglycone함량을 측정하였다. Yang 등(44)은 대두의 식품 제조공정 중 비배당체 형태를 증가시키기 위해서는 고온에 의한 전환이나 $\mathrm{HCl}$ 과 같은 산을 이용하는 방법보다는 $\beta$-glucosidase효소활성이 높은 천연물질을 활용하는 것이 유리하다고 하였다. 또한 고온 이나 강산을 이용한 반응의 경우 반응산물이 무작위적이고 부반응에 의해 효율이 저하될 수 있는 반면, 천연물 유래의 $\beta$-glucosidase 효소를 활용하는 경우 반응산물의 선택성을 증가시킬 수 있으며 유해한 유기용매의 사용을 감소시킬 수 있다고 하였다. 따라서 별미장으로 분리된 $\beta$-glucosidase 활성이 있는 B. subtilis $\mathrm{HJ} 18-9$ 균주를 접종하여 품종별로 청국장을 제조함으로써 isoflavone 비배당체 함량을 유의적 으로 증가시키는 결과를 얻어낸 본 실험은 많은 활용도가 있을 것으로 사료된다.

\section{요 약}

본 연구에서는 $\beta$-glucosidase활성이 있는 B. subtilis $\mathrm{HJ} 18$-9균을 접종하여 품종별로 청국장을 제조하여, 품종별 청국장의 품질특성과 isoflavone 함량 변화를 측정한 결과 이다. 청국장의 단백질 분해 특유의 구수한 맛 성분을 유리 하는 효소인 protease활성은 발효 전에는 새단백 청국장이 가장 높은 활성을 나타냈으며, 발효 후에는 우람 청국장이 가장 높은 protease활성을 나타냈다. 이는 구수한 맛 성분의 지표성분인 아미노태 질소함량과 같은 경향을 나타냈다. 환원당을 유리하는데 관여하는 a-amylase 활성은 새단백으 로 제조한 청국장이 다른 품종에 비해 유의적으로 높은 함량을 나타냈으며 다섯가지 품종 모두 발효 후에 증가하는 경향을 나타냈다. 발효 후에 총 균수가 높아지는 경향을 나타냈으며 발효 초에는 우람 청국장이 유의적으로 높은 균수를 나타냈으나, 발효 후에는 품종 간에 유의적인 차이 는 나타내지 않았다. 품종별 청국장의 isoflavone 함량은 발효초기에는 대풍, 우람 품종으로 제조한 청국장의 aglycone함량이 가장 높았으며, 48 시간 발효 후에도 두 가지 품종이 각각 $1249.04 \pm 9.14 \mathrm{ug} / \mathrm{g}, 589.32 \pm 14.08 \mathrm{ug} / \mathrm{g}$ 로 가장 높은 aglycone 전환율 나타냈다. 이는 발효 초 aglycone함량 에 비해 $5.31,1.94$ 배 증가시켰다.

\section{감사의 글}

본 연구는 농촌진흥청 국립농업과학원 시험연구비(과제 번호:PJ008533)에 의해 수행되었다.

\section{References}

1. Messina M (1995) Modern applications for an ancient bean : soybeans and the prevention and treatment of chronic disease. J Nutr, 567S-569S

2. Stanford JL, Herrinton LJ, Schwartz SM, Weiss NS (1995) Breast cancer incidence in Asian migrants to the United States and their descendants. Epidemic, 6, 181-183

3. Stephens (1999) The rising incidence of breast cancer in women and prostate cancer in men. Dietary influences : a possible preventive role for nature's sex hormone modifiers-the phytoestrogens (review). Oncol Rep, 6, 865-870

4. Barnes S (1998) Evolution of the health benefits of soy isoflavones. Proc Soc Exp Biol Med, 217, 386-392

5. Fotsis T, Pepper M, Adlercreutz H, Hase T, Montesano $\mathrm{R}$, Schweigerer L (1995) Genistein, a dietary ingested isoflavonoid, inhibits cell proliferation and in vitro angiogenesis. J Nutr, 125, 790-797

6. Setchell KD, Cassidy A (1999) Dietary isoflavone : biological effects and relevance to human health. J Nutr, 129, 758-767

7. Setchell KD, Borriello SP, Hulme P, Kirk DN, Axelson M (1984) Non steroidal estrogens of dietary origin : possible role in hormone dependent disease. Am J Clin Nutr, 40, 569-578

8. Kim EM, Lee KJ, Chee KM (2004) Comparison in isoflavone contents between soybean and soybean sprout of various soybean cultivas. Korean J Nutr, 37, 4551-4555

9. Wang HJ, Murphy PA (1996) Mass balance study of Isoflavone during soybean processing. J Agric Food Chem, 44, 2377-2383

10. Setchell KDR, Brown NM, Desai P, Zimmer-Nechemias L, Wolfe BE, Brashear WT (2001) Bioavailability of pure isoflavones in healthy humans and analysis of commercial soy isoflavone supplements. J Nutr, 131, 1362-1375

11. Choe JS, Kim JS, Yoo SM, Park HJ, Kim TY, Chang CM, Shin SY (1996) Survey on preparation method and consumer response of Chungkukjang. Korean Soybean Digest, 13, 29-43

12. Iwai K, Nakaya N, Kawasaki Y, Matsue H (2002) Antioxidative functions of natto, a kind of fermented soybeans : effect on LDL oxidation and lipid metabolism in cholesterol fed rats. J Agric Food Chem, 50, 3597-3601

13. Seo HR, Kim JY, Kim JH, Park KY (2009) Identification of Bacillus cereus in a chungkukjang that showed high 
anticancer effects against AGS human gastric adenocarcinoma cells. J Med Food, 12, 1274-1280

14. Kim SS, Lee JH, Ahn YS, Kim JH, Kang DK (2003) A fibrinolytic enzyme from Bacillus amyloliquefaciens D4-7 isolated from chunggukjang : its characterization and influence of additives on thermostability. Korean $\mathbf{J}$ Microbiol Biotechnol, 31, 271-276

15. Lee SY, Kim JY, Baek SY, Yeo SH, Koo BS, Park HY, Choi HS (2011) Isolation and identification characteristics of oligotrophic strains with high enzyme activity from buckwheat sokseongjang. Korean J Food Sci Technol, 43, 735-741

16. Yoon KS (1998) Changes of enzymatic activities during the fermentation food soybean-soypaste by Aspergillus spp. MS Thesis. Konkuk University, Korea

17. KFDA(2005) Food Code. Korea Food \& Drug Administration, Cheongwon, Korea.

18. Chae SK, Kang KS, Ma SJ, Bang GW, Oh MH, Oh SH (2000) In Standard Food Analysis. Gigumunhwasa, Seoul, Korea, p 299-301

19. Weatherburn MW (1967) Phenol-hypochorite reaction for determination of ammonia. J Anal Chem, 39, 971-974

20. Uzzan M and Labuza TP (2004) Critical issues in R\&D of soy isoflavone enriched foods and dietary supplements. J Food Sci, 69, 77-86

21. Wang G, Kuan SS, Francis OJ, Ware GM, Carman AS (1990) Simplified HPLC method for determination of phytoestrogens in soybean and its processed product. J Agric Food Chem, 38, 185-190

22. Kim JH, Yoo JS, Lee CH, Kim SY, Lee SK (2006) Quality properties of soybean pastes made from meju with mold producing protease isolated from traditional meju. J Korean Soc Appl Biol Chem, 49, 7-14

23. Lee NR, Go TH, Lee SM, Hong CH, Park KM, Park GT, Hwang DY, Son HJ (2013) Characteristics of chungkookjang prepared by Bacillus amyloliquefaciens with different soybeans and fermentation temperatures Korean J Microbio, 49, 71-77

24. Ann YG (2011) Changes in components and peptides during fermentation of cheonggukjang. Korean $\mathrm{J}$ Food Nutr, 24, 124-131

25. Youn KC, Kim DH, Kim JO, Park BJ, Yook HS, Cho JM, Byun MW (2002) Quality characteristics of the chungkookjang fermented by the mixed culture of Bacillus natto and B. licheniformis. J Korean Soc Food Sci Nutr, 31, 204-210

26. Kim MH (2009) Comparison of quality characteristics and functional effects of Chunggukjang prepared with various soybean cultivars. MS Thesis. Chonbuk National University, Korea, p 45-46

27. Ra KS, Oh SH, Kim JM, Suh HJ (2004) Isolation of fibrinolytic enzyme and $\beta$-glucosidase producing strains from Doenjang and optimum conditions of enzyme production. J Korean Soc Food Sci Nutr, 33, 439-442

28. Ryu BH (2003) Development of functional Doenjang for antioxidative and fibrinolytic activity. J Life Sci, 13, 559-568

29. Yoo SK, Cho WH, Kang SM, Lee SH (1999) Isolation and identification of microorganisms in Korean traditional soybean paste and soybean sauce. Korean $\mathbf{J}$ Microbiol Biotechnol, 27, 113-117

30. Mann SY, Kim EA, Lee GY, Kim DY (2013) Characteristics of Chungkookjang produced by Bacillus subtilius MC31. J Life Sci, 23, 560-568

31. Kim KM, Kim HR, Yoo SM, Kim JS, Choe JS (2006) Quality characteristics of Chunggugjang prepared by Bacillus subtilis NRLSI IV with different inoculum levels and fermentation temperatures. Korean J Food Cookery Sci, 22, $291-298$

32. Kim MH, Han SY, Ko JM, Kim YS (2012) Degradation characteristics of proteins in Cheonggukjang (fermented unsalted soybean paste) prepared with various soybean cultivars. Food Sci Biotechnol, 21, 9-18

33. Hwang JH (2010) The fermentative characteristics of Cheonggukjang prepared by starter culture of Bacillus spp. with fibrinolytic activity. J Korean Soc Food Sci Nutr, 39, 1832 - 1838

34. Zheng YF, Jeong JK, Choi HS, Park KY (2011) Increased quality characteristics and physiological effects of Chunggukjang fermented with Bacillus subtilis-SKm. J Korean Soc Food Sci Nutr, 40, 1694-1699

35. Hwang HA, Lee NK, Choi IJ, Hagm YT, Kwon KO, Kim BY (2008) Selected of microorganisms and optimimization of manufacture process for cheonggukjang. Korean J Food Sci Techol, 40, 406-411

36. Ju KE, Oh NS (2009) Effect of the mixer culture Bacillus subtilis and Lactobacillus plantarum on ther quality of Cheonggukjang. Korean J Food Sci Techol, 41, 399-404

37. Shon MY (1999) Physicochemical properties and biological activities of Chungkuk-jang produced from Korean black bean. $\mathrm{Ph}$ D Thesis. Gyeongsang National University, Korea

38. Kim JW, Kim YS, Jeong PH, Kim HE, Shin DH (2006) Physicochemical characteristics of traditional fermented 
soybean products manufactured in folk villages of Sunchang region. J Fd Hyg Safety, 21, 223-230

39. Oh HI, Eom SM (2008) Changes in microflora and enzyme activities of Cheonggukjang prepared with germinated soybeans during fermentation. Korean J Food Sci Technol, 40, 56-62

40. Baek LM, Park LY, Park KS, Lee SH (2008) Effect of starter cultures on the fermentative characteristics of cheonggukjang. Korean J Food Sci Technol, 40, 400-405

41. Jung JB, Choi SK, Jeong DY, Kim YS, Kim YS (2012) Effects of germination time of soybeans on quality characteristics of cheonggukjang fermented with an isolated bacterial strain. Korean J Food Sci Technol, 44, 69-75
42. Bae EA, Kwon TW, Moon GS (1997) Isoflavone contents and antioxidative effects of soybeans, soybean curd and their by-products. J Korean Soc Food Sci Nutr, 26, 371-375

43. Shon MY, Seo KI, Lee SW, Choi SH, Sung NJ (2000) Biological activities of chungkugjang prepared with black bean and changes in phytoestrogen content during fermentation. Korean J Food Sci Technol, 32, 936-941

44. Yang SO, Chang PS, Baek BK, Hong SD, Lee JH (2007) Change of isoflavone distribution in soybeans using almond powder. Korean J Food Sci Technol, 39, 231-236 